\title{
Distribution of Heritage Association of Harta Pusaka Tinggi And Harta Pusaka Rendah in Padang Pariaman
}

\author{
Elfia $^{1}$, Meirison ${ }^{2}$, Qasim Muhammadi ${ }^{3}$ \\ 1,2UIN Imam Bonjol Padang, ${ }^{3}$ ICCORA, Iran \\ e-mail: 1elfiamag@uinib.ac.id, ${ }^{2}$ meirison@uinib.ac.id, ${ }^{3}$ Qmuhammadi@iccora.com
}

\begin{abstract}
This research is motivated by a phenomenon of the distribution of inheritance that occurs in the Nagari Lurah Ampalu community. They hand over inheritance (pusako rendah) at the pusaka tingg" property to girls. Some of the problems in this study are, the factors causing the community to divide pusaka tinggi and pusaka rendah are not based on Islamic law and the method of settlement by Shari'a for the two types of inherited assets that have been mixed. Data in this paper were obtained through interviews and documentation. The factors causing the community to share this inheritance are derived from the traditions of previous ancestors, the lack of community knowledge in faraid science and the existence of coercion between heirs. The solution used by local clerics is to calculate the price of pusaka tinggi land and the proceeds of the sale are left to the pusaka tinggi property holders. Assets that are on ancestral inheritance are distributed to heirs according to the law of farä'id. The final solution is to move or eliminate assets above pusaka tinggi.
\end{abstract}

Keyword: inheritance, pusaka tinggi, pusaka rendah, farāil

Penelitian ini dilatarbelakangi oleh suatu fenomena pembagian harta warisan yang terjadi di masyarakat Nagari Lurah Ampalu. Mereka menyerahkan harta warisan (pusako rendah) yang berada di lokasi harta pusaka tinggi kepada anak perempuan. Beberapa masalah dalam penelitian ini yaitu, faktor penyebab masyarakat melakukan pembagian harta pusaka tinggi dan pusaka rendah tidak berdasarkan hukum Islam dan cara penyelesaian secara syariat terhadap dua jenis harta warisan yang telah bercampur itu. Data dalam tulisan ini diperoleh melalui wawancara dan dokumentasi. Adapun faktor penyebab masyarakat membagi warisan ini bersumber dari tradisi nenek moyang terdahulu, minimnya pengetahuan masyarakat dalam ilmu faraid dan adanya keterpaksaan antara ahli waris. Solusi yang digunakan oleh ulama lokal yaitu menghitung harga tanah pusaka tinggi dan hasil penjualannya diserahkan kepada pemegang harta pusaka tinggi. Aset yang berada di atas tanah pusaka nenek moyang dibagikan kepada ahli waris yang ada menurut hukum faräitid. Solusi terakhir adalah memindahkan atau mengeliminasi aset yang ada di atas pusaka tinggi.

Kata Kunci: warisan, pusaka tinggi, pusaka rendah, farāiț 


\section{Introduction}

The theme in this study is the distribution of inheritance from a mixture of pusaka tinggi and pusaka rendah which is located in Nagari Lurah Ampalu District VII Koto Sungai Sariak, Padang Pariaman Regency. This paper examines the implementation of the distribution of inheritance that is in the location of pusaka tinggi assets carried out by the Nagari Lurah Ampalu community. The Nagari Village of Ampalu as a whole embraces Islam and adheres to the matrilineal kinship system.

Harta pusaka tinggi are inheritance received from the grandmother on the part of the mother or has been spelled out generations. ${ }^{1}$ In this case, pusaka tinggi in the form of ulayat land. While pusaka rendah are treasures resulting from the search for a husband and wife in a marriage. A man who tries to be with his wife, the treasure obtained has a separate position in the Minangkabau indigenous community, which is called treasure search. Pusaka Rendah in this case a permanent house. The purpose of the mixture of pusaka tinggi and pusaka rendah property is a house that was built by the heir to be on pusaka tinggi land (ulayat land). ${ }^{2}$ The house that was built by an heir came from a treasure when heir lived. After the heir dies, the house is immediately taken over by his wife or daughter who lives in the house, without sharing it with other heirs. ${ }^{3}$

According to one of the heirs, the inheritance of a mixture of pusaka tinggi and pusaka tinggi left by parents is the right of women. So, a man who is in the house, if he is married, then he goes to the wife's house or goes abroad with his wife. ${ }^{4}$ This is influenced by the kinship system adopted by the Nagari Lurah Ampalu community, namely the matrilineal kinship system. They assume that pusaka rendah in the form of houses built on pusaka tinggi land, is passed on to

\footnotetext{
${ }^{1}$ Manan Rajo Panghulu Mahmud Sutan, Himpunan Tambo Minangkabau dan Bukti Sejarah (Bukittinggi: Ma’arif, 1978), 82.

2Iskandar Kama, Beberapa Aspek dari Hukum Kewarisan Matrilineal Kebilateral di Minangkabau, dalam Mukhtar Naim (Padang: Center for Minangkabau Studies, 1968), 12; Yeni Salma Barlinti, 'Inheritance Legal System in Indonesia: A Legal Justice for People', Indonesia Law Review3, no. 1(2014): 23.

${ }^{3}$ Iman J, 'Normative Analysis Approach: Status and Rights of a Daughter under Islamic Inheritance Law in Indonesia', Sociology and Criminology 4, no. 2 (2016).

4 Irawaty Irawaty; Diyantari Diyantari, 'Inheritance Laws in Indonesia', Hayula: Indonesian Journal of Multidisciplinary Islamic Studies 1, no. 2 (2017): 99.
} 
girls. Distribution of inheritance like this has long been practiced and is a custom passed down from the ancestors. ${ }^{5}$

Examples of cases that occurred in Korong Sawah Liek. First, the heir named Siti Sawiyah, died on June 8, 2014, leaving behind the heirs of her husband, 1 sister, 5 daughters and one son. In this case, the inheritance in the form of a house located on the customary land was not distributed to the existing heirs, but was taken by the most powerful daughter among the heirs. Secondly, heirs named Burhanuddin, died in 1999 leaving an heir of 2 wives, 2 daughters and 8 sons. Burhanuddin left a legacy in the form of two houses in the land of pusaka tinggi, his wife respectively. So, the house in Sawah Liek was inherited by his first wife and the house in Koto Marapak was inherited by his second wife along with their respective children. ${ }^{6}$

Furthermore, the case of the distribution of inheritance in Korong Sikilir, the heir named Siti Aminah, died in 2017, leaving behind an heir of her husband, 2 sons and 2 daughters and 3 siblings. Leaving the inheritance in the form of a plot of house on the customary land taken by a daughter. Another case of distribution of inheritance occurred in Surau Village. Heir named Aluih, died in 2007, leaving an heir of 1 daughter, 3 sisters and 4 brothers. Leaving an inheritance in the form of a permanent home on communal land and several other inheritances taken by a daughter. ${ }^{7}$ Based on some of the cases above it can be seen that in the distribution of inheritance there is a mixture of pusaka tinggi with pusaka rendah in the Nagari Lurah Ampalu community in a different case form.

According to Darwis, former guardian of Nagari Lareh Nan Panjang for the period of 2011-2017, each Nagari in District VII of Koto Sungai Sariak, generally distributed inheritance from a mixture of pusaka tinggi and pusaka rendah, to women. The number of korong and population contained in the Nagari Lurah Ampalu is more than the other Nagari, so the researchers chose Nagari Lurah

\footnotetext{
${ }^{5}$ Kama, Beberapa Aspek dari Hukum Kewarisan Matrilineal Kebilateral di Minangkabau, dalam Mukhtar Naim, 29.

6Interview with Mardiana on March 20, 2018 in Lareh Nan Panjang about "Portion of Inheritance Rights"

7William Marsden, The History of Sumatra: Containing an Account of the Government, Laws, Customs, and Manners of the Native Inhabitants, with a Description of the Natural Production, and a Relation of the Ancient Political State of That Island (London: W. Marsden, 1783), 33.
} 
Ampalu as the location of the study. ${ }^{8}$ Meanwhile, according to the Minangkabau tradition, the distribution of pusaka tinggi from ancestors according to maternal lineage, is passed down along the customs. While the search treasure according to adat is a low heirloom treasure according to the rules of sharia. ${ }^{9}$ Therefore, the case described above contradicts the customary rules which divide the inheritance in the form of low inheritance according to the provisions of sharia (al-Nisā' '(4) Paragraph 7).

Based on observations that have been made, many found very interesting things to discuss in this study. In the literature on Minangkabau custom, especially regarding inheritance of wealth from a mixture of high heirlooms and low heirlooms, there are many diverse facts. There are things that are in accordance with what is written in the literature but many are not appropriate. For example, inheritance inherited from the female lineage is only a high heirloom, but in reality, does not occur in Nagari Lurah Ampalu. ${ }^{10}$ It can be said that the inheritance that was distributed to women, namely the mixture of pusaka tinggi and pusaka rendah in the Ampalu village was a new discovery. It can be said that the people of Nagari Lurah Ampalu, in terms of the distribution of inheritance, have experienced a cultural shift. The subject matter examined is What is the basis of the inheritance distribution system in Nagari Lurah Ampalu? How did the traditional leaders and local ulama respond to the distribution of inheritance in Nagari Lurah Ampalu? What is the solution according to Islamic law to complete the distribution of inheritance from the mixing of pusaka tinggi and pusaka rendah in Nagari Lurah Ampalu? Through field studies, the basis of the community to divide the inheritance from a mixture of pusaka tinggi and pusaka rendah in Nagari Lurah Ampalu will be revealed. Data obtained through interviews with people who share the inheritance of the mixture. After the data is obtained, analyzed and described in this paper.

\section{Inheritance Discourse in Minangkabau}

Inheritance law is a rule governing the transfer of assets of a person who passed away to his heir. This means determining who is the heir, the portion of

\footnotetext{
8Interview with Darwid on April 8, 2018 in Lereh Nan Panjang with the theme of Mixed Heritage Properties of High and Low Heritage

${ }^{9}$ Amir Syarifuddin, Hukum Kewarisan Islam (Jakarta: Kencana, 2005), 4.

${ }^{10}$ Amir M.S Magek Bapayuang, Adat Minangkabau Pola dan Tujuan Hidup Orang Minang (Jakarta: Citra Harta Prima, 2011), 67.
} 
each heir, determining the inheritance of the deceased person. ${ }^{11}$ In addition, the author also discusses the inheritance which will be distributed to the heirs of dhaw al-furüd. Inheritance is the property of someone who dies, which can be used freely during his lifetime, after deducting the cost of the body (tajhiz almayit). ${ }^{12}$ while inheritance according to Minangkabau custom is the inheritance and title (customary position; jabatan adat) received by someone from another person who has died.13 Inheritance there is called "harta pusaka" which is something that is material in someone who has died who can be transferred to another person solely due to his death. In the above definition, the word "material" is put forward to distinguish it from sako, which is the transfer that applies from the dead to the living in the form of a degree of greatness in custom. Use the word "solely due to death" to distinguish it from "grants; hibah".14 Some kinds of inheritance in Minangkabau are explained as follows.

\section{Harta Pusaka Tinggi (High Heritage)}

High heritage are assets that have been owned for generations from previous generations so that their origin is unclear to the recipient. In some areas, it is also called an old treasure (harta tua) because it is too old for life. The special features of the high heritage are: 1) The exact origin is unknown. 2) The owner is a group together for a common interest. 3) Ownership cannot change hands outside the people unless it can be done by the people together as well.

High inheritance is known as ancestral arable inheritance inherited from hereditary mamak on the nephew of a people so it is a high heirloom treasure of the people. It cannot be shared or sold and in a forced state may be mortgaged. He belongs to the people of my own tribe. In its management, especially land, customary provisions that read:

Ganggam bauntuk

Hak bapunyo,

Milik bamasiang

\footnotetext{
${ }^{11}$ Amir Syarifuddin, Pelaksanaan Hukum Kewarisan Islam dalam Lingkungan Adat Minangkabau (Jakarta: Gunung Agung, 1994), 50.

12Sayyid Sabiq, Fiqih Sunnah (Jakarta: Pena Pundi Aksara, 2006), 202.

${ }^{13}$ Chairul Anwar, Hukum Adat Indonesia: Meninjau Hukum Adat Minangkabau Jakarta: Rineka Cipta, 1997), 1.

${ }^{14}$ Syarifuddin, Pelaksanaan Hukum Kewarisan Islam dalam Lingkungan Adat Minangkabau, 212.
} 
This means that the right to manage the property is shared fairly by the oldest woman still in the tribe. The results, which are managed by each group of people, can be utilized by those groups..$^{15}$ The function of these assets are: 1) as the union of a people with blood ropes. 2) As a reminder that all people will relate to the nobility of their ancestors. 3) As an example for the next generation to always think of future generations.

In essence, high heritage property in its management does not conflict with Islamic inheritance rights, because the property is shared property, not personal property. Common property in the name of one people and many people cannot be divided according to Islamic law. High treasures in Minangkabau are assets passed down from generation to generation, not shared for ownership. ${ }^{16}$

In principle, heirlooms should not be sold or pawned, as the saying goes: dijua tak dimakan bali, digadai tak dimakan sando (sold may not be purchased, pawned must not be taken hostage). High heirlooms may be mortgaged or sold for the common good, with the agreement of all members, if circumstances force. These interests are: First, maik tabujua ditangah rumah is to finance the death ceremony of respected tribal members. Second, managak gala pusako is to finance the headman exchange. Third, gadih gadang indak balaki that is for the marriages of tribal members. Fourth, rumah gadang katirisan that is for the cost of repairing a traditional house or exchanging it.

However, at present, the conditions for pawning or selling heirlooms are somewhat loose. It is used as capital for trading, paying off debt, education costs, pilgrimage costs and health. ${ }^{17}$

\section{Harta Pusaka Rendah (Low Heritage)}

Low Heritage Property (pusaka rendah or harta pencarian) is a property that is damaged by a person or group, which can be known with certainty its origin. This can happen if the inheritance is passed down by parents and mamak,

\footnotetext{
${ }^{15}$ Syarifuddin, Hukum Kewarisan Islam, 29.

${ }^{16}$ Yasrul Huda, 'Islamic Law Versus Adat: Debate about Inheritance Law and the Rise of Capitalism in Minangkabau', Studia Islamika2 15, no. 2 (2008), http://journal.uinjktac.id/index.php/studiaislamika/article/view/531.

17Diyantari, 'Inheritance Laws in Indonesia', 99.
} 
or two levels above which heirs can still be recognized..$^{18}$ Harta Pencarian means assets obtained from the results of one's own business, when single or after marriage, either by managing heirlooms or other work, such as trading or obtaining from other people's gifts or grants. ${ }^{19}$ The search property consists of movable property, such as jewelry, cars, houses and others or immovable property, such as rice fields and fields.

Inheritance as a treasure that is received by someone as an inheritance from one's own mother, automatically becomes the personal property concerned. Management and results are also automatically an addition to the personal search property concerned. As private property, low inheritance assets by themselves can be sold or gifted to anyone the owner wants. ${ }^{20}$ This low inheritance treasure has been passed on to his children and is called "implantable assets" which in the future play a big role in adding to the high heirlooms in Minangkabau, which will guarantee the welfare of the people, both in the Minang realm and overseas.

Pusaka rendah described above is a treasure for parents to inherit from their children, both boys and girls, as well as gifts from mamak (mother's brother). Inheritance of wealth is carried out according to Islamic provisions, men get twice as much as women. For example, if the heirs of two sons and three daughters are counted in total like seven people, two sons are counted four and a total of three women because one woman is still counted as one.

Historically the Minangkabau tradition has undergone several changes, especially for inheritance issues that have been agreed upon and decided in a urang nan ampek jihih meeting throughout West Sumatra on 2-4 Mai 1952 in Bukittinggi, followed by ninik mamak, ulema, and the younger generation who came as envoys from all Minangkabau realms. According to the density, two basic principles are set in settling the inheritance, namely: 1) harta pusaka tinggi that have been passed down from generation to generation from the maternal line, handed down according to custom. 2) Search property or harta pusaka rendah is lowered according to shariah regulations. The agreement is a

\footnotetext{
18J, “Normative Analysis Approach.”

${ }^{19}$ Safruddin Halimi Kamaluddin, Adat Minangkabau dalam Perspektif Hukum Islam Analisa Fiqh terhadap Sistem Matrilineal, Larangan Kawin Sesuku dan Hukum Waris Adat Minangkabau (Padang: Hayfa, 2005), 89.

${ }^{20}$ Bapayuang, Adat Minangkabau Pola dan Tujuan Hidup Orang Minang, 31.
} 
compromise between sharia and custom. Sharia has released pusaka tinggi to be inherited in a customary manner and regulates the inheritance of pusaka rendah.

The four jinih agreements were strengthened through the Minangkabau traditional law seminar, July 21-25, 1968 in Padang, the contents of which are as follows. First, harta pusaka tinggi in Minangkabau is a legal entity's property, administered and represented by the mamak head of inheritance, where the mamak head of inheritance or nephew is not the owner of the legal entity's assets. Second, harta pusaka rendah is inherited according to farä'id law. Search property is one-half of the assets obtained during marriage coupled with one's own inheritance (private property not belonging to the people). Third, a person is justified in his will to his nephew or to another maximum of one third of the search property. ${ }^{21}$

\section{History and Geographical Location of Nagari Lurah Ampalu}

Nagari Lurah Ampalu is one of the villages in the District VII of Koto Sungai Sariak, Padang Pariaman Regency. Based on history told by ninik mamak Nagari Lurah Ampalu, this nagari is a relatively hilly and bumpy nagari and is a fraction of Nagari Ampalu. Nagari Ampalu was originally one of the seven Nagari in Koto District VII. The seven villages are: Nagari Sungai Sariak, Nagari Sungai Dalam, Nagari Tandikek, Nagari Batu Kalang, Nagari Koto Dalam, Nagari Koto Baru, and Nagari Ampalu.

In 1916, Nagari Ampalu was split into three villages, namely 1) Nagari Lurah Nan Panjang became Nagari Lareh Nan Panjang based in Ampalu, 2) Nagari Lurah Balah Aia became Nagari Balah Aia centered in Koto Baru, 3) Nagari Lurah Ampalu was Centered in Barangan.

Since long time ago, the paddy farming sector in the paddy fields has been a hereditary effort in Nagari Lurah Ampalu District VII Koto. In the dry season, the Nagari Lurah Ampalu community irrigates their fields with a stream of banda (irrigation) so that this area is central to rice production in the Nagari Lurah Ampalu (2015 Government Report (LPPN), 4). The population of Nagari Lurah Ampalu is $\pm 6,531$ people, with details of 3,255 men and 3.30 women. The 90.

${ }^{21}$ Syarifuddin, Pelaksanaan Hukum Kewarisan Islam dalam Lingkungan Adat Minangkabau, 289- 
number of households is 1,678 households (KK) consisting of non-poor families 1,234 families (Report on the Implementation of Nagari Government (LPPN)) $2015,7)$. Implementation of population development can be a determinant of the policy direction of Nagari's activities, bearing in mind that Nagari's assets have a dual role, both as subjects and as objects of activity. ${ }^{22}$ In general, the people of Nagari Lurah Ampalu look for farmers as farmers, the crop commodities produced include $985 \mathrm{Ha}$ of paddy rice. Plantations covering an area of 922 Ha with relatively good production levels and have been supported by $1105 \mathrm{Ha}$ facilities and good agricultural infrastructure, in addition there are also those engaged in the cultural sector of marine and brackish fisheries. ${ }^{23}$ The people of Nagari Lurah Ampalu generally live well, no one is starving and all of them have houses that are occupied. The community helps each other to help each other. That is what causes people to live prosperously and peacefully.

\section{Social and Cultural Life of the Community}

The application of customary law in the life of the Nagari Lurah Ampalu community is very strong. Every problem faced is always done by way of deliberation by ninik mamak people. The Nagari Lurah Ampalu community in the inheritance system adheres to the matrilineal kinship system. Matrilineal kinship system is a kinship system according to the maternal line. The Nagari people of the Ampalu Urban Village live in tribes, namely the Koto, Caniago, Tanjuang, Jambak and others. Nevertheless, the Nagari Lurah Ampalu people live in peace and harmony. There are two to four tribes in a village, but there is one village that only consists of one tribe, namely Korong Sawah Liat.

The traditions that are always carried out by the Nagari Lurah Ampalu community include:

\section{Indigenous in Marriage}

Marriage in the custom of the Nagari Lurah Ampalu community that the man was bought or commonly known as pickup, where the pickup was in

\footnotetext{
${ }^{22}$ Interview with Darwis on April 8, 2018 in Lereh Nan Panjang with the theme of Mixed Heritage Properties of High and Low Heritage.

${ }^{23}$ Kamaluddin, Adat Minangkabau dalam Perspektif Hukum Islam Analisa Fiqh terhadap Sistem Matrilineal, Larangan Kawin Sesuku dan Hukum Waris Adat Minangkabau, 21-22.
} 
accordance with the agreement between the two parties, both male and female mamak. This marital problem was originally called batimbang tando.

Community traditions in marriage events use the mutual cooperation system. This tradition aims to help families who are having a party. In the morning, mothers help cook, serve food, after which it is continued by adolescent girls. While at night it is the duty of the boys to serve food to the invited guests for the night of the Islamic boarding school. On badantam night, people are required to pay a house fee of Rp. 20,000.

\section{Customary Death}

One tradition that has never been abandoned by the people of Nagari Lurah Ampalu is the habit of bringing 1 liter of rice to the funeral home in the jorong. After the bodies were buried, a three-day Qur'an event was held at the funeral home. The event was named manigo hari. The next seven days, ampek puluah hari and the last is maratuih hari. On the hundredth day a tahlilan was known as the badikia (dhikr) which was conducted by several Labai and Ungku people. After carrying out the customary tradition of death, if the wealth of the deceased is excessive and there is still a lot it will be given to the rightful heirs. ${ }^{24}$

The Nagari Lurah Ampalu community is a homogeneous, religious community, and the nature of mutual cooperation is still relatively high. This can be seen from the activities of community cooperation in the implementation of development, both sourced from government assistance and nongovernmental organizations, both in the form of providing construction sites and community participation in their implementation, such as in building mosques, cleaning villages, building roads and cleaning existing roadsides. in their respective villages, building irrigation channels, disaster management, and marriage and death activities.

According to the writer's observation, the community has a high social life. Every activity carried out, always done together. For people who do not want to participate, he will be ostracized and people are also reluctant to help. In addition, the community is also compliant with customary rules, for example in the customary death community is required to hold a mando'a event. Even

\footnotetext{
${ }^{24}$ Interview with Amrizal on 21 January 2019 about the inheritance of Pusako Tinggi Ampalu Village in Sawah Liat Wali Korong Sawah Liek
} 
though the bereaved family does not have the money to carry it out, this tradition is still practiced.

\section{Factors Causing the Distribution of Inheritance from Mixed High and Low Heritage}

The distribution of inheritance in Islam is based on the Qur'an and Hadith. Whereas the people of Nagari Lurah Ampalu shared the inheritance by means of their own understanding which was based on the traditions of their ancestors. Asyiah explained that "In the past, our ancestors gave inheritance to girls, while men only guarded inheritance. This is because in Minang the matrilineal kinship system is adopted."25 This is caused by several factors as follows:

\section{The Lack of Knowledge About the Distribution of Inheritance in Islam}

Following are the results of interviews with heirs about the distribution of inheritance in Islam.

a. Actors (heirs)

An heir named Mar stated that:

"Inheritance is a property left by a deceased family and passed on to his children. The difference with the inheritance I do not understand. Pusaka tinggi is inheritance inherited from the mamak in the nephew, while pusaka rendah is inheritance inherited from the father or parent to the child. I do not understand the distribution of inheritance which is regulated in Islam".

Furthermore, the heir named Amir who resides in Sikilir stated that

"Inheritance is a property left by a deceased person to a living person. Inheritance in Minangkabau is passed on to girls. Because men in Minangkabau play the role of guardians of property not as property owners".

Agustina, a resident of Sawah Liat, stated:

"In my opinion, inheritance is the property left by relatives who have died. People who inherit are children, siblings, husbands or wives. The distribution of inheritance in Islam does not understand. Pusaka tinggi is a treasure left by ancestors from generation to generation, may be divided

\footnotetext{
25Interview with Nur Asyiah on 29 December 2018about Public Opinion in Pusako Tinggi in Sawah Liat Wali Korong Sawah Liek
} 
but may not be traded. While pusaka rendah are assets that are bought or sought by fathers and may be traded " 26

She also explained that the heirlooms are inherited from the ancestors to their children and grandchildren so they cannot be traded and the assets reach their children and grandchildren. If the children and grandchildren develop, then the property can only be divided and may not be sold. To my knowledge, the inheritance is divided equally so that no disputes occur. While low inheritance may be traded because of the search for fathers while they were still alive and divided equally, in general, those who get the inheritance are daughters.

Furthermore, a statement from Mardiana, an heir stated

"after my father died, his inheritance in the form of money and gold was taken by his brother without first holding a deliberation. While the house that my mother and father had built during his marriage was inherited by my mother. Because the house stood on the land of my mother's family's pusaka tinggi. While another house which was built on pusaka tinggi land, my father's second wife was inherited by my father's second wife. This is because the house stands on the land of their respective pusaka tinggi so that they cannot be contested". 27

b. Public

Asyiah, a resident of Sawah Liat said:

"To my knowledge, inheritance is property left by people who have died. Comparison of the distribution of inheritance is $2: 1$, namely men twothirds while women half, who get the inheritance are children, husband and grandchildren. Pusaka tinggi are heirlooms handed down by ancestors (Pusako Tuo) controlled by mamak and handed down to nephews and should not be shared, while pusaka rendah are father's treasure, these treasures are not shared but if there is a request will be given a little."28

Asyiah also explained that in Minangkabau, particularly in Nagari Lurah Ampalu, in general, share inheritance to daughters, either high heirlooms or low heirlooms. In the past, after my grandmother died, who left a legacy of some gold, my parents and siblings shared the inheritance

\footnotetext{
26Interview with Agustina on 29 December 2018 about inheritance, Nagari Pariaman in Sawah Liat Wali Korong Sorong Liek

27Interview with Mardiana on March 20, 2018 in Lareh Nan Panjang about "Portion of Inheritance Rights"

${ }^{28}$ Interview with Nur Asyiah on 29 December 2018about Public Opinionin Pusako Tinggi in Sawah Liat Wali Korong Sawah Liat.
} 
with their sisters only by dividing evenly, while his brothers did not get an inheritance because men if they had left overseas did not obtain property. legacy again. Especially with pusaka rendah that are above the pusaka tinggi cannot be sold and requested by men because they are wholly owned by girls. ${ }^{29}$

Aside from Asyiah, Reni, as the community of Sawah Liat, also said that:

"Inheritance assets are the property of people who have died and become full rights of the owner. Heirs are people who have the closest relationship with the deceased, for example are children, grandchildren, siblings and parents, if the wife dies the husband is not entitled to inheritance left by the wife because the child is everything but if the husband dies the inheritance left behind may be the wife got it. The distribution of inheritance between boys and girls is $2: 1 " .30$

Reni also explained, in Minangkabau, the inheritance is divided into two, pusaka tinggi and pusaka rendah. Pusaka tinggi is an inheritance inherited from generation that cannot be bought and sold which is passed down from mamak to nephew. Whereas the pusaka rendah, that is, assets purchased by parents given to children and can be sold. the distribution is divided equally. Furthermore, if the pusaka rendah is located above the pusaka tinggi should not be divided, because the pusaka rendah is on the pusaka tinggi land where it is given to girls.

Besides Eli Desni as a resident of Sikilir said:

"I do not understand what is called inheritance or all matters relating to the inheritance, because I did not go to school, let alone going to primary school, I did not graduate". 31

The same thing was said by Yendra Yeni, a resident of Kampung Surau: "I do not know what is meant by inheritance, what I know is only pusako treasure. Pusako assets are assets left by people who have died, for example in the form of land and houses. Pusako property in Minangkabau is divided into two, namely pusaka tinggi and pusaka rendah. First, pusaka tinggi are

\footnotetext{
${ }^{29}$ Kamaluddin, Adat Minangkabau dalam Perspektif Hukum Islam Analisa Fiqh terhadap Sistem Matrilineal, Larangan Kawin Sesuku dan Hukum Waris Adat Minangkabau, 51.

${ }^{30}$ Interview with Nur Asyiah on 29 December 2018about Public Opinion in Pusako Tinggi in Sawah Liat Wali Korong Sawah Like.

31 Interview with Desni Eli about Education Level on 10 February 2019 in Sawah Liat.
} 
the inheritance from ancestors obtained by generations. Second, pusaka rendah is a treasure from the mother and father." 32

Yeni explained that the people of Kampung Surau generally distributed inheritance assets that were not in accordance with the provisions contained in the Qur'an because we did not know and did not understand the method of division contained therein. If a relative dies and leaves the inheritance, we divide the inheritance equally, so there is no fighting. Inheritance that is distributed equally will not cause chaos and quarrels between families who died. ${ }^{33}$

Furthermore, with a different editorial but having the same intention, Murni, a trader, the village of Surau explained:

"Heritage property is the same as pusako treasure. An inheritance is a treasure left by ancestors to their children and grandchildren. Heritage property consists of two kinds, first, the tambilang ameh treasure, the property given to children after parents die. Second, tambilang basi assets are assets that were passed down from the mamak to the nephew after the mamak passed away. The method of distribution is, if pusaka rendah is divided by a ratio of $2: 1$, while pusaka tinggi is divided by a ratio of $1: 2$, one portion for boys and two parts for girls. But at present most women are only in power. As for the distribution of pusaka rendah that are located on the land of pusaka tinggi, they may not be owned by men but may be used as temporary dwellings".34

Pak Len, a Sikilir resident, said:

"I as a layman only understand that inheritance is the property of a person who has died. Understanding from the heirs I do not understand, the most important people who receive an inheritance is the family of the deceased. As for how the distribution of inheritance I do not understand."35

\section{There is an Element of Compulsion Between Heirs}

Agustina explained the distribution of inheritance that occurred in her family:

\footnotetext{
32Interview with Yendra Yeni about Inheritance in Minangkabau on 10 February 2019in Kampung Surau.

${ }^{33}$ Kamaluddin, Adat Minangkabau dalam Perspektif Hukum Islam Analisa Fiqh terhadap Sistem Matrilineal, Larangan Kawin Sesuku dan Hukum Waris Adat Minangkabau, 33; Barlinti, 'Inheritance Legal System in Indonesia: A Legal Justice for People', 24.

${ }^{34}$ Interview with Murni about the Distribution of High and Low Heritage on 10 February 2019 in Sawah Liat

35Interview with Mardiana on March 20, 2018 in Lareh Nan Panjang about "Portion of Inheritance Rights"
}

52 || Vol 30, No 1, April 2020 
"When my grandmother was still alive she had several parcels of land belonging to a pusaka tinggi which was then given to her daughter to build a house, then there were several fields of rice fields and a house located on top pusaka tinggi land. After my grandmother died, my parents held a discussion with their siblings about the distribution of inheritance, but the second brother of my parents did not agree to be divided because my grandmother still owed the debt to my mande (mother) and did not mention the important amount of my grandmother's debt very much and until now the rice field is still taken by my parents' sister. While the house which is located on pusaka tinggi land was also taken by my parents' sister. My parents and four other siblings remained patient and gave their younger siblings over disputes and besides, my parents also made a house on the high inheritance land given by my grandmother to my parents while her younger siblings had left and also have a family life there". 36

An heir named Mar who now resides in Bungin said:

"After my parents died, my parents 'relatives asked for part of the inheritance. I did not want to give it because it was my parents' property. bequeathed to his child so that a fight broke out between me and my mother's brother. One day my mamak or my parents 'siblings invited to negotiate to solve this problem. Results from mamak deliberations and my parents' other siblings still gave the inheritance of my parents To me, the consideration is that the inheritance is my right because it is the result of searching for my parents, plus I don't have a husband and have four children so my mother feels sorry for me. In exchange, my mamak gave my mother's pusaka tinggi in the form of a coconut tree located on pusaka tinggi land. Later, my parents' siblings accepted it even though they were not happy with the decision".

Based on the above interview, it can be understood that the people of Nagari Lurah Ampalu in general do not know how to distribute inheritance according to the provisions stipulated in the Qur'an and Hadith. During this time, people do the distribution of inheritance based on the habits of their respective ancestors. In addition to the above factors, there are other factors that cause the community to divide inheritance from a mixture of pusaka tinggi and pusaka rendah, which is influenced by the educational background of the community.

\section{The Responses of Customary Leaders and Local Ulemas To Distribution of Inheritance in Nagari Lurah Ampalu}

Customary leader and ulama figure are an important person in a community. They are role models and a place to ask questions for the

\footnotetext{
36Interview with Agustina on 29 December 2018 about inheritance, Nagari Pariaman in Sawah Liat Wali Korong Sorong Liek
} 
community. In a village usually the community is very obedient and reluctant to the scholars and traditional leaders. As for the scholars who are called and ordered, surely the community will follow, without knowing the legal basis of something that is governed. According to the cleric figures, the distribution of inheritance that occurs in the community is not in accordance with Islamic inheritance law, but it has been a hereditary tradition since before. From the responses of the scholars above it can be understood that the knowledge of the scholars and traditional leaders in the distribution of inheritance according to Islam is very minimal.

The following are the results of the author's interviews with religious and traditional leaders of several jorong in Nagari Lurah Ampalu

\section{Religious Leaders}

A local ulema named Nursuhup, an ungk $u^{37}$ who lives in Sawah Liat, said:

"Provisions for the distribution of inheritance in Islam are found in the Qur'an, especially in Surah al-Nisā'. But the distribution of inheritance specified in the Qur'an I do not understand. The heirs who are entitled to receive the inheritance are children, wife / husband and parents. In the Minangkabau tradition, there are two types of inheritance, pusaka tinggi and pusaka rendah. Pusaka tinggi are treasures from ancestors handed down to children and grandchildren while heirlooms are the treasure of parents searching for life".

The next interview was with Ungku Jasman who was in Surau al-Hijrah while the teacher recited the mosque in Surau.

"Inheritance is the distribution of wealth from the father after he dies. While harta peninggalan is pre-existing assets, for example, paddy fields, fields commonly referred to as stale tambilang assets, classified as heirs is someone left by the heirs who have a close relationship with someone who has died. The distribution of inheritance is contained in the Qur'an $1 / 2$ for boys, girls get $2 / 3$ and $1 / 6$ for mothers. Furthermore, in the Minangkabau tradition, inheritance is classified into two forms, namely pusaka tinggi and pusaka rendah. Pusaka tinggi or tambilang basi are treasures that have existed since the past, for example palak (gardens) and rice fields, while pusaka rendah are father's property when they were still alive."38

\footnotetext{
${ }^{37}$ Ungku is a cleric as a place to ask the public about religious knowledge, the Imam of the tarweh prayer in the month of Ramadan, giving weekly lectures in the mosque and at the house of the yasinan, khatib (Friday prayers, Eid al-Fitr and Eid al-Adha) and prayers at the homes of people who are die.

38Interview with Jasman Nudin about Heritage of High Heritage (Sawah Ladang) on February 10 2019 in Ampalu
} 
Besides that, Ungku Jasman explained that pusaka tinggi in Minangkabau should not be traded because it was a gift. While pusaka rendah may be shared and traded because it is the father's search for life. But if there is a mixture of pusaka tinggi and pusaka rendah in which a house in the form of pusaka rendah that stands on pusaka tinggi land, then his house can be divided while the land is not. But if there is a fight over the distribution of inheritance, it must be resolved by the ninik mamak. If it is not completed then it can be brought to the authorities to resolve the dispute over the assets. Because if it is brought to the ulama the property is legitimate divided because in Islam all assets left by the testator are the rights of the heirs. In Islam, inheritance is not divided into pusaka tinggi and pusaka rendah.

A similar thing was explained by an Ungku Surau Bungo Tanjuang named Deka Putra.

"Inheritance is a legacy from someone who has passed away inherited by relatives. An heir is a person left by someone who has passed away, belonging to the heir is his wife, children and parents. The distribution of inheritance is contained in the Qur'an and in more detail is contained in a book of Jurisprudence. For more details, the division looks at who are the heirs left by the testator. Pusaka is the same as the inheritance. Pusaka tinggi is a treasure cultivated by people who have been for example (rice fields and fields) passed down from generation to generation. Whereas pusaka rendah that is, property purchased from people who have passed away. Regarding the mixing of pusaka tinggi and pusaka rendah, it should be discussed with traditional leaders, according to the scholars, the inheritance is still distributed to the heirs, both from high and low heirlooms."

Furthermore, Labai ${ }^{39}$ Nurudin also explained that inheritance is a property left by a deceased person to a person who is still alive.

\section{Traditional Figure}

Subsequently explained by Dervish he was also a ninik mamak who was in Sawah Liat that:

"Pusaka tinggi is an inheritance inherited from an unclear ancestor whose real owner is given to the mother while pusaka rendah is the father's treasure search during his life given to children. Pusaka tinggi is inherited along the custom while pusaka rendah is given in a farä'id manner. But if there is a mixture of

\footnotetext{
${ }^{39}$ Labai is a person who is in charge of leading five daily prayers, taking care of the dead, starting from bathing to burying and carrying out the mando' $a$ to the homes of residents ata certain time.
} 
pusaka tinggi and pusaka rendah in the form of houses that are located above pusaka tinggi, then look back on the existing originals first. If the first is land, the inheritance is distributed according to customary provisions, ie given to girls. In addition, the inheritance is also useful for the benefit of children for girls in Minangkabau because it is the only legacy from their parents". 40

Mak Am Baluang, concerning the distribution of pusaka tinggi and pusaka rendah in Nagari Lurah Ampalu said:

"Mixing pusaka tinggi and pusaka rendah in the form of houses standing on pusaka tinggi, should not be sold and should not be divided because they stand on pusaka tinggi belonging to the people. Pusaka tinggi should not be traded because it was donated for the benefit of a woman in Minangkabau, especially in Nagari Lurah Ampalu. The benefit here is for Minangkabau women and children not to live in hardship without a place to live in a land of people. However, if pusaka rendah, the inheritance of parents in the form of a father's house and land, a car, etc., can be distributed in a farä'id manner and the distribution is returned to the heirs in the house related to the method and all kinds of things."

Lack of community curiosity on the issue of inheritance to the scholars.

Ungku Deka explained:

"I have never resolved the problem of inheritance distribution because in general the community only negotiates with the next of kin and never asks the scholars to resolve this inheritance problem".41

Ungku Nursuhup also explained:

"The distribution of inheritance carried out by the people here I do not know. Because I have never resolved the inheritance dispute that occurred in Nagari Lurah Ampalu or elsewhere. In general, if inheritance issues occur, the community only resolves with the family system together with their ninik mamak or with their siblings."

Based on the statement of the religious leaders above, itcan be said that they lack knowledge of how to distribute inheritance contained in the Qur'an and Hadith. While religious leaders serve as role models for the community. It can be said that these people also do not understand the distribution of inheritance and share the inheritance according to their knowledge.

\footnotetext{
40Interview with Darwis on April 8, 2018 in Lereh Nan Panjang with the theme of Mixed Heritage Properties of High and Low Heritage.

41 Interview with Putra Deka Putra Deka tengtang Heirs of High and Low Heritage on 10 February 2019 in Sawah Liat
} 


\section{The Perspective of Islamic Law in Completing the Distribution of Inheritance from the Mix of Pusaka Tinggi and Pusaka Rendah in Nagari Lurah Ampalu}

The distribution of inheritance in Islam has been established in the Qur'an and hadiths and follows a bilateral system. It is different from what is understood or applied by the people of Nagari Lurah Ampalu who give the whole inheritance to women, both in the type of high inheritance and low inheritance. While in the Qur'an the man also inherits twice the share of women, bearing in mind that men bear the cost of living, dependents, business expenses, and bear all the problems. This is in accordance with the provisions stipulated in Surah al-Nisā' '(4) Paragraph 11. In the hadith also arranged the distribution of inheritance, as narrated by Ibn 'Abbas.

As for Minangkabau, the inheritance is divided into two, pusaka tinggi and pusaka rendah. Pusaka tinggi is the inheritance of a female mamak, like a mother who has a plot of land if she dies, it will fall to her granddaughter. Pusaka tinggi only have usage rights, not to be inherited nor are they granted..$^{42}$ This is done to keep Minangkabau daughters from suffering in the future. Nevertheless, some Minangkabau people still carry out the distribution of inheritance according to the provisions of Islamic law (farā'id law) on pusaka rendah. As the Minangkabau traditional saying is adat basandi syara', syara' basandi kitabullah. But in the case that the author pointed out there is a difference with the theory stated above because pusaka tinggi and pusaka rendah are mixed in one treasure so that the distribution is difficult to do by the community. In the case of such mixing, inheritance is given to girls only.

Some of the solutions put forward by the ulama leaders in the case of the distribution of inheritance from a mixture of pusaka tinggi and pusaka rendah in Nagari Lurah Ampalu namely, first, calculate the price of the house according to current housing prices, then submit it to the existing heirs. Second, knock down the house that is above pusaka tinggi land, so there is no dispute between the heirs. If this is done it will bring harm not to benefit the heirs.

\footnotetext{
${ }^{42}$ J, 'Normative Analysis Approach: Status and Rights of a Daughter under Islamic Inheritance Law in Indonesia'.
} 
In this case, the author prefers the first solution because it provides more benefits and benefits for the heirs than the second solution that brings harm to the heirs.

\section{Conclusion}

First, the factors that cause the distribution of inheritance are a mixture of pusaka tinggi with pusaka rendah in Nagari Lurah Ampalu, are those 1) own knowledge derived from the traditions of previous ancestors. 2) the lack of public knowledge about the distribution of inheritance according to Islam. 3) there is a compulsion factor between heirs.

Second, according to ulema and traditional leaders, the practice of distributing inheritance in the community is not in accordance with Islamic inheritance law, but has been a hereditary tradition since before. Some said it was in accordance with Shariah because the property was above the pusaka tinggi so that it could be inherited by women. Distribution of inheritance that is mixed with pusaka tinggi with pusaka rendah is difficult in its distribution. So that the scholars and traditional leaders let it, as long as there is no quarrel.

Third, the solutions provided by religious leaders are 1) calculating the price of pusaka tinggi land and the proceeds from the sale are left to the holders of pusaka tinggi assets. After that, the price of the house can be distributed to the heirs according to farä'id law. 2) Knocking down houses that are on pusaka tinggi land. Both of these solutions are good, but the heirs must choose what is best for their benefit.[a]

\section{BIBLIOGRAPHY}

Anwar, Chairul. Hukum Adat Indonesia: Meninjau Hukum Adat Minangkabau. Jakarta: Rineka Cipta, 1997.

Bapayuang, Amir M.S Magek. Adat Minangkabau Pola dan Tujuan Hidup Orang Minang. Jakarta: Citra Harta Prima, 2011.

Barlinti, Yeni Salma. 'Inheritance Legal System in Indonesia: A Legal Justice for People'. Indonesia Law Review 3, no. 1 (2014).

Diyantari, Irawaty Irawaty; Diyantari. 'Inheritance Laws in Indonesia'. Hayula: Indonesian Journal of Multidisciplinary Islamic Studies 1, no. 2 (2017). 
Huda, Yasrul. 'Islamic Law Versus Adat: Debate about Inheritance Law and the Rise of Capitalism in Minangkabau'. Studia Islamika2 15, no. 2 (2008). http://journal.uinjkt.ac.id/index.php/studia-islamika/article/view/531.

J, Iman. 'Normative Analysis Approach: Status and Rights of a Daughter under Islamic Inheritance Law in Indonesia'. Sociology and Criminology 4, no. 2 (2016).

Kama, Iskandar. Beberapa Aspek dari Hukum Kewarisan Matrilineal Kebilateral di Minangkabau, dalam Mukhtar Naim. Padang: Center for Minangkabau Studies, 1968.

Kamaluddin, Safruddin Halimi. Adat Minangkabau dalam Perspektif Hukum Islam Analisa Fiqh terhadap Sistem Matrilineal, Larangan Kawin Sesuku dan Hukum Waris Adat Minangkabau. Padang: Hayfa, 2005.

Marsden, William. The History of Sumatra: Containing an Account of the Government, Laws, Customs, and Manners of the Native Inhabitants, with a Description of the Natural Production, and a Relation of the Ancient Political State of That Island. London: W. Marsden, 1783.

Sabiq, Sayyid. Fiqih Sunnah. Jakarta: Pena Pundi Aksara, 2006.

Sutan, Manan Rajo Panghulu Mahmud. Himpunan Tambo Minangkabau dan Bukti Sejarah. Bukittinggi: Ma'arif, 1978.

Syarifuddin, Amir. Hukum Kewarisan Islam. Jakarta: Kencana, 2005.

- - - Pelaksanaan Hukum Kewarisan Islam dalam Lingkungan Adat Minangkabau. Jakarta: Gunung Agung, 1994. 
